\title{
Structural Elucidation of Two New Chromones Isolated from Glasswort (Salicornia europaea L.)
}

\author{
Yoshihito AraKawa, Hideyuki ChiJ and Masao Izawa* \\ Department of Agricultural Chemistry, Faculty of Agriculture, \\ Hokkaido University, Sapporo 060, Japan
}

Received February 3, 1983

\begin{abstract}
Two chromones isolated from the methanol extract of glasswort (Salicornia europaea L.) were elucidated to be 7-hydroxy-6-methoxychromone and 7.O'- $\beta$-D-glucopyranosyl-6-methoxychromone on the basis of chemical and spectral analyses and synthetic studies. These two are natural products hitherto unknown.
\end{abstract}

In a previous paper, ${ }^{1)}$ we have reported that four compounds were isolated from the reddish leaves and stems of glasswort and Compounds I, II and III were determined to be 2'-hydroxy-6,7-methylenedioxyisoflavone, $(-)-(2 S)-2^{\prime}$-hydroxy-6,7-methylenedioxyflavanone and 2',7-dihydroxy-6-methoxyisoflavone, respectively.

This report deals with the structural elucidation of Compound IV and a further Compound $\mathrm{V}$ which has now been obtained from this plant.

The molecular formula of Compound IV obtained as white needles was determined to be $\mathrm{C}_{10} \mathrm{H}_{8} \mathrm{O}_{4}$ (calcd. for $\mathrm{C}_{10} \mathrm{H}_{8} \mathrm{O}_{4}:$ 192.0422) by high resolution MS (a molecular ion peak, $\mathrm{m} / \mathrm{z}$ 192.0417). The NMR spectrum (DMSO- $d_{6}$ ) of this compound showed two doublets at $\delta 8.10$ $(1 \mathrm{H}, J=6 \mathrm{~Hz})$ and $\delta 6.19(1 \mathrm{H}, J=6 \mathrm{~Hz})$, which were proved to be coupled with each other by the spin-decoupling technique. By considering the chemical shifts and splitting patterns, these two signals were attributable to the protons at C-2 and C-3 of the chromone nucleus or at C-4 and C-3 of the coumarin nucleus. A carbonyl absorption in the IR spectrum $\left(1640 \mathrm{~cm}^{-1}\right)$ coincides well with those of chromones $\left(1640 \sim 1660 \mathrm{~cm}^{-1}\right)$ but it is situated in a region lower than those of coumarins $\left(1720 \sim 1740 \mathrm{~cm}^{-1}\right)$. Consequently, Compound IV was estimated to be one of the chromone compounds.

In the NMR spectrum, a singlet at $\delta 3.85$ $(3 \mathrm{H})$ evidently indicates the existence of one methoxyl group. As Compound IV gave a positive reaction (grayish blue) by FolinCiocalteu reagent, this compound was subjected to methylation and acetylation, and monomethyl $\left(\mathrm{M}^{+}, m / z\right.$ 206) and monoacetyl derivatives $\left(\mathrm{M}^{+}, m / z\right.$ 234) were respectively obtained. Therefore, the presence of one phenolic hydroxyl group was proved. The binding sites of the two substituents to the chromone nucleus were determined to be situated at C-6 and $\mathrm{C}-7$, because the signals of two aromatic protons were observed as two respective singlets at $\delta 7.33(1 \mathrm{H}, \mathrm{H}-5)$ and $\delta 6.90(1 \mathrm{H}, \mathrm{H}-8)$. The binding site of the hydroxyl group was established by a comparison of the chemical shifts of the protons at C-5 and C-8 in the NMR spectra of the methyl and acetyl derivatives. Signals of the C-5 and C-8 protons of the acetyl derivative appeared in the lower magnetic field by 0.11 and $0.36 \mathrm{ppm}$, respectively, than those of the methyl derivative. This means that the acetyl group links to the C-7 position. Furthermore, a bathochromic shift was observed in the UV spectrum when sodium acetate was added. These facts support that the hydroxyl group links to the C-7 position and the methoxyl group is bonded to the C-6 position. Thus, Compound IV was

* Present address: The Rakunogakuen College of Dairying, Ebetsu, Hokkaido 069-01, Japan. 
estimated to be 7-hydroxy-6-methoxychromone. To confirm this estimated structure, we attempted to synthesize this compound. The spectral data of the synthesized compound 5 agreed well with those of the natural Compound IV.

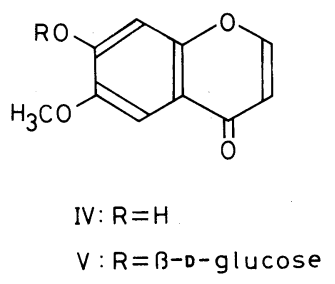

The molecular formula of Compound $\mathrm{V}$ obtained as white powder from the butanolsoluble fraction was determined to be $\mathrm{C}_{16} \mathrm{H}_{18} \mathrm{O}_{9}$ by the presence of a peak, $\mathrm{m} / \mathrm{z}$ 355.0994 , corresponding to $(\mathrm{M}+\mathrm{H})^{+}$(calcd. for $\left.\mathrm{C}_{16} \mathrm{H}_{19} \mathrm{O}_{9}, 355.1029\right)$ in the FD-high resolution MS spectrum. The UV spectrum of this compound showed absorption maxima at 226 ( $\log \varepsilon 4.11), 246 \mathrm{sh}$ (3.79), $270 \mathrm{sh}$ (3.66) and $317 \mathrm{~nm}$ (3.81). In the IR spectrum, a carbonyl absorption was observed at $1633 \mathrm{~cm}^{-1}$. Two respective doublets $(1 \mathrm{H}, J=6 \mathrm{~Hz})$ appeared at $\delta 8.19$ and $\delta 6.26$ in the NMR spectrum. These spectral data were similar to those of Compound IV. Consequently, Compound V was suggested to be one of the chromone compounds. The presence of sugar in Compound $\mathrm{V}$ was proved by the anthrone test $^{2)}$ and also the signals at $\delta 4.4 \sim 5.5$ and $3.6 \sim 3.9$ in the NMR spectrum were estimated to be originated from the sugar. The NMR spectrum also showed that a singlet assigned to the protons of the methoxyl group appeared at $\delta 3.86$. The methoxyl group and sugar are estimated to be linked to C-6 and C-7 of the chromone nucleus, because two singlets ascribed to the aromatic protons were observed at $\delta 7.38(\mathrm{H}-5)$ and $\delta 7.28(\mathrm{H}-8)$.

Compound $\mathrm{V}$ was subjected to an acid hydrolysis with trifluoroacetic acid. The watersoluble fraction (sugar moiety) obtained from the hydrolyzate was concentrated and examined for sugars by paper chromatography (PC). A spot showing the $R f$-value correspond- ing to D-glucose was observed. After concentration, the chloroform-soluble fraction from the hydrolyzate gave an aglycone compound, whose UV, IR, MS and FT-NMR spectral data and an $R f$-value in TLC were proved to be identical with those of Compound IV, i.e., 7-hydroxy-6-methoxychromone.

With $\beta$-glucosidase, Compound V could be hydrolyzed to give D-glucose, which was detected by PC. In the NMR spectrum, a signal ascribed to the anomeric proton of $\beta$-D-glucose could not be observed because of concealing by the signals of hydroxyl groups, but, after the addition of deuterium oxide, it was detected clearly as a doublet at $\delta 5.16(J=7 \mathrm{~Hz})$. These findings indicated that D-glucose was linked to the aglycone by a type of $\beta$-bonding.

Consequently, Compound V was elucidated to be 7-O- $\beta$-D-glucopyranosyl-6-methoxychromone.

The naturally-occurring 2,3-unsubstituted chromones hitherto isolated and identified are as follows: 5,7-dihydroxychromone from the shells of peanut (Arachis hypgoea) (Leguminosae) $^{4)}$ and the seeds of Polygonum persicaria (Polygonaceae), ${ }^{5)}$ leptorumol and its 4-methoxy-D-glucoside (leptorumolin) from Leptorumohra miqueliana $\mathrm{H}$. Ito (Aspidiaceae), ${ }^{6)}$ 5-hydroxychromone-7-rutinoside from Mentha longifolia Hudson (Labiatae), ${ }^{7)}$ and 6,7-methylenedioxychromone and 6,7-dimethoxychromone from glasswort (Salicornia europaea L.) (Centrospermae). ${ }^{8)}$

Therefore, the two chromones described here are new compounds which have never been previously obtained from natural sources.

\section{EXPERIMENTAL}

Measurements of melting points and UV, IR, Mass and NMR spectra were carried out in a similar manner to those reported previously. ${ }^{1)}$ FD-mass spectral data were obtained with a JEOL JMS-01SG-2. FT-NMR spectra were taken at $100 \mathrm{MHz}$, using a JNM-FX 100 FT NMR spectrometer. Thin-layer chromatography (TLC) was run on silica gel plates (Kiesel gel nach Stahl, Typ 60) with solvent $\mathrm{A}, \mathrm{CHCl}_{3}-\mathrm{EtOH}(9: 1, \mathrm{v} / \mathrm{v})$. Paper chromatog- 
raphy (PC) was conducted, using Toyo-Roshi paper No. 50 and either solvent B, 1-propanol-ethyl acetate-water $(7: 1: 2, v / v)$, or solvent C, 2-propanol-water $(4: 1, \mathrm{v} / \mathrm{v})$. Column chromatography was carried out with silica gel (Wako gel C-200) and activated charcoal (Wako Chemicals Co.).

Isolation of compounds. Reddish leaves and stems of glasswort (fresh weight $52 \mathrm{~kg}$ ) were extracted with methanol. After removal of the solvent, the concentrate was extracted with ether and then with 1-butanol. The ethersoluble fraction gave Compounds I ( $81 \mathrm{mg})$, II $(45 \mathrm{mg})$, III $(20 \mathrm{mg})$ and IV $(25 \mathrm{mg})$ by means of silica gel column chromatography and fractional crystallization. ${ }^{1)}$ The butanol-soluble fraction was concentrated and chromatographed on a silica gel column employing a $\mathrm{CHCl}_{3}-$ $\mathrm{MeOH}$ mixture as the solvent system. The fraction eluted with $\mathrm{CHCl}_{3}-\mathrm{MeOH}(80: 20, \mathrm{v} / \mathrm{v})$ was applied to activated charcoal column chromatography and eluted with a water-acetone mixture. The fraction eluted with wateracetone $(50: 50, \mathrm{v} / \mathrm{v})$ was rechromatographed on a silica gel column, which was then eluted with a chloroformmethanol mixture, monitoring by ultraviolet absorption $(356 \mathrm{~nm})$. The fraction eluted with $\mathrm{CHCl}_{3}-\mathrm{MeOH}(85: 15$, $\mathrm{v} / \mathrm{v})$ was concentrated and crystallized from the wateracetone mixture to give Compound V $(15 \mathrm{mg})$ as a white powder.

Physicochemical properties of the isolated compounds and their derivatives.

1) Compound $I V . \mathrm{mp}: 231 \sim 232^{\circ} \mathrm{C}$. High $\mathrm{MS} \mathrm{m} / z$ : $192.0417\left(\mathrm{M}^{+}\right)$, Calcd. for $\mathrm{C}_{10} \mathrm{H}_{8} \mathrm{O}_{4}:$ 192.0422. UV $\lambda_{\max }^{\mathrm{MeOH}} \mathrm{nm}(\log \varepsilon): 226$ (4.20), $233 \mathrm{sh}$ (4.06), 280 (3.76), 317 (3.97); + NaOMe $242 \mathrm{sh}, 250 \mathrm{sh}, 347$; + NaOAc $232 \mathrm{sh}$, 280, 326. IR $v_{\max }^{\mathrm{KBr}} \mathrm{cm}^{-1}: 3450(\mathrm{OH}), 3080,2970,2920$, 2860, $1640(\mathrm{C}=\mathrm{O}), 1625,1590,1555$. MS $m / z: 192\left(\mathrm{M}^{+}\right.$, base peak), 191, 177, 163, 162, 149. NMR $\delta_{\text {TMS }}^{\text {DMSO-d }}$ ppm: $8.10(1 \mathrm{H}, \mathrm{d}, J=6 \mathrm{~Hz}, \mathrm{H}-2), 7.33(1 \mathrm{H}, \mathrm{s}, \mathrm{H}-5), 6.90(1 \mathrm{H}, \mathrm{s}$, $\mathrm{H}-8), 6.19$ ( $1 \mathrm{H}, \mathrm{d}, J=6 \mathrm{~Hz}, \mathrm{H}-3), 3.85$ (3H, s, MeO). FolinCiocalteu reagent, grayish blue.

2) Methyl derivative of Compound IV. An ethereal solution of diazomethane was added to a solution of Compound IV $(8 \mathrm{mg})$ in a small amount of absolute methanol. After standing overnight, the mixture was concentrated to give the methyl derivative $(7 \mathrm{mg})$ as white needles. $\mathrm{mp}: 162 \sim 163^{\circ} \mathrm{C}$ (lit. ${ }^{9)} 163^{\circ} \mathrm{C}$ ). UV $\lambda_{\max }^{\mathrm{EtOH}} \mathrm{nm}$ ( $\log \varepsilon$ ): 228 (4.17), 233 (4.17), 275 (3.68), 316 (3.90). IR $v_{\max }^{\mathrm{KBr}} \mathrm{cm}^{-1}: 1640(\mathrm{C}=\mathrm{O})$. MS $m / z: 206\left(\mathrm{M}^{+}\right.$, base peak), $205,191,177,176,175,163,137,135$. NMR $\delta_{\mathrm{TMS}}^{\mathrm{CDCl}_{3}} \mathrm{ppm}$ : $7.78(1 \mathrm{H}, \mathrm{d}, J=6 \mathrm{~Hz}, \mathrm{H}-2), 7.52(1 \mathrm{H}, \mathrm{s}, \mathrm{H}-5), 6.84(1 \mathrm{H}, \mathrm{s}$, $\mathrm{H}-8), 6.29$ (1H, d, $J=6 \mathrm{~Hz}, \mathrm{H}-3), 3.98(6 \mathrm{H}, \mathrm{s}$, two $\mathrm{MeO})$.

3) Acetyl derivative of Compound IV. To a solution of Compound IV $(7 \mathrm{mg})$ in dry pyridine $(1 \mathrm{ml})$ was added acetic anhydride $(1 \mathrm{ml})$. After standing overnight, the reaction mixture was poured into ice-cooled water and extracted with chloroform. Upon evaporation of the chloroform, the acetyl derivative was obtained as white needles
(5 mg). mp: $91 \sim 92^{\circ} \mathrm{C}$. UV $\lambda_{\max }^{\mathrm{EtOH}} \mathrm{nm}(\log \varepsilon): 226(4.44), 246$ (4.14), 316 (4.01). IR $v_{\max }^{\mathrm{KBr}} \mathrm{cm}^{-1}: 1760$ (AcO), $1650(\mathrm{C}=\mathrm{O})$. MS $m / z: 234\left(\mathrm{M}^{+}\right), 192$ (base peak), 191, 177, 163, 149. NMR $\delta_{\mathrm{TMS}}^{\mathrm{CDCl}_{3}} \mathrm{ppm}: 7.81(1 \mathrm{H}, \mathrm{d}, J=6 \mathrm{~Hz}, \mathrm{H}-2), 7.63(1 \mathrm{H}, \mathrm{s}$, H-5), 7.20 (1H, s, H-8), $6.29(1 \mathrm{H}, \mathrm{d}, J=6 \mathrm{~Hz}, \mathrm{H}-3), 3.90$ $(3 \mathrm{H}, \mathrm{s}, \mathrm{MeO}), 2.34$ (3H, s, AcO).

4) Compound $V$. mp: $228 \sim 229^{\circ} \mathrm{C}$. FD-High $\mathrm{MS} m / z$ : 355.0994 $(\mathrm{M}+\mathrm{H})^{+}$, Calcd. for $\mathrm{C}_{16} \mathrm{H}_{19} \mathrm{O}_{9}: 355.1029$. UV $\lambda_{\max }^{\mathrm{EtOH}} \mathrm{nm}(\log \varepsilon): 226(4.11), 246 \mathrm{sh}$ (3.79), $270 \mathrm{sh}$ (3.66), 317 (3.81). IR $v_{\max }^{\mathrm{KBr}} \mathrm{cm}^{-1}: 3000 \sim 3650(\mathrm{OH}), 2930,1633$ $(\mathrm{C}=\mathrm{O}), 1595,1515$. FD-MS $\mathrm{m} / \mathrm{z}: 393(\mathrm{M}+\mathrm{K})^{+}, 377$ $(\mathrm{M}+\mathrm{Na})^{+}, 355(\mathrm{M}+\mathrm{H})^{+}$(base peak), $354\left(\mathrm{M}^{+}\right), 191$ $\left(\mathrm{M}^{+}-\mathrm{C}_{6} \mathrm{H}_{11} \mathrm{O}_{5}\right)$. NMR $\delta_{\text {TMS }}^{\text {DMSO-d }}{ }_{6}$ ppm: $8.19(1 \mathrm{H}, \mathrm{d}, J=$ $6 \mathrm{~Hz}, \mathrm{H}-2), 7.38(1 \mathrm{H}, \mathrm{s}, \mathrm{H}-5), 7.28(1 \mathrm{H}, \mathrm{s}, \mathrm{H}-8), 6.26(1 \mathrm{H}$, d, $J=6 \mathrm{~Hz}, \mathrm{H}-3), 4.4 \sim 5.5\left(5 \mathrm{H}, \mathrm{m}, \mathrm{OH}-\mathrm{sugar}\right.$ and $\left.\mathrm{H}^{-1} \mathbf{1}^{\prime}\right)$, $3.86(3 \mathrm{H}, \mathrm{s}, \mathrm{MeO}), 3.6 \sim 3.9\left(6 \mathrm{H}, \mathrm{m}, \mathrm{H}-2^{\prime}, 3^{\prime}, 4^{\prime}, 5^{\prime}, 6^{\prime}\right)$. NMR $\delta_{\mathrm{TMS}}^{\text {DMSO- } d_{6}+\mathrm{D}_{2} \mathrm{O}} \mathrm{ppm}$ : $5.16\left(1 \mathrm{H}, \mathrm{d}, J=7 \mathrm{~Hz}, \mathrm{H}-1^{\prime}\right)$. Anthrone-sulfuric acid reaction, ${ }^{2)}$ greenish blue.

5) Acetyl derivative of Compound $V$. To a solution of Compound V $(7 \mathrm{mg})$ in dry pyridine $(1 \mathrm{ml})$ was added acetic anhydride $(1 \mathrm{ml})$. After standing overnight, the reaction mixture was poured into ice-cooled water and extracted with chloroform. Upon evaporation of the chloroform, the residue was recrystallized from ethanol to give the acetyl derivative $(6 \mathrm{mg})$ as white needles. $\mathrm{mp}$ : $135 \sim 136^{\circ} \mathrm{C}$. UV $\lambda_{\max }^{\mathrm{EtOH}} \mathrm{nm}(\log \varepsilon): 227 \quad(4.20), 244 \mathrm{sh}$ (3.93), $270 \mathrm{sh}$ (3.68), 316 (3.90). IR $v_{\max }^{\mathrm{KBr}} \mathrm{cm}^{-1}: 2950,1775$ (AcO), $1655(\mathrm{C}=\mathrm{O}), 1630,1510$. MS $m / z: 331,271,193$, 192, 191, 169 (base peak), 163, 145, 109, 103. FD-MS $m / z$ : $522\left(\mathrm{M}^{+}\right.$, base peak), 331, 191. NMR $\delta_{\mathrm{TMS}}^{\mathrm{CDCl}_{3}} \mathrm{ppm}: 7.80$ $(1 \mathrm{H}, \mathrm{d}, J=6 \mathrm{~Hz}, \mathrm{H}-2), 7.57$ (1H, s, H-5), $7.18(1 \mathrm{H}, \mathrm{s}, \mathrm{H}-8)$, $6.30(1 \mathrm{H}, \mathrm{d}, J=6 \mathrm{~Hz}, \mathrm{H}-3), 5.1 \sim 5.4\left(4 \mathrm{H}, \mathrm{m}, \mathrm{H}-1^{\prime}, 2^{\prime}, 3^{\prime}\right.$, $\left.4^{\prime}\right), 4.23\left(2 \mathrm{H}, \mathrm{m}, \mathrm{H}-6^{\prime}\right), 3.91(3 \mathrm{H}, \mathrm{s}, \mathrm{MeO}), 3.79 \sim 3.96(1 \mathrm{H}$, $\left.\mathrm{m}, \mathrm{H}-5^{\prime}\right), 2.10(3 \mathrm{H}, \mathrm{s}, \mathrm{AcO}), 2.08(3 \mathrm{H}, \mathrm{s}, \mathrm{AcO}), 2.06(3 \mathrm{H}, \mathrm{s}$, $\mathrm{AcO}), 2.05$ (3H, s, AcO).

6) Acid hydrolysis products of compound $V$. Compound $\mathrm{V}(3 \mathrm{mg})$ was dissolved in aqueous $10 \%$ trifluoroacetic acid $(1 \mathrm{ml})$, and the solution was refluxed in a sealed tube for $1 \mathrm{hr}$. After the tube had been opened, the trifluoroacetic acid was evaporated and the residue was dissolved in water. The aqueous solution was extracted with chloroform. The chloroform layer was concentrated to give a white powder (1.5 mg, aglycone of Compound V). UV $\lambda_{\max }^{\mathrm{MeOH}} \mathrm{nm}: 227,233 \mathrm{sh}, 279,317$. IR $v_{\max }^{\mathrm{KBr}} \mathrm{cm}^{-1}: 1640$ $(\mathrm{C}=\mathrm{O})$, 1625. MS $m / z$ : $192\left(\mathrm{M}^{+}\right.$, base peak), 191, 177, $163,162,149$. FT-NMR $\delta_{\mathrm{TMS}}^{\mathrm{DMSO}_{6}}$ ppm: $8.13(1 \mathrm{H}, \mathrm{d}, J=$ $6 \mathrm{~Hz}, \mathrm{H}-2), 7.35(1 \mathrm{H}, \mathrm{s}, \mathrm{H}-5), 6.93(1 \mathrm{H}, \mathrm{s}, \mathrm{H}-8), 6.21(1 \mathrm{H}$, $\mathrm{d}, J=6 \mathrm{~Hz}, \mathrm{H}-3), 3.86(3 \mathrm{H}, \mathrm{s}, \mathrm{MeO})$. TLC: $R f 0.55$ in solvent A (7-hydroxy-6-methoxychromone 0.55 ).

On the other hand, the aqueous layer was used for the identification of sugar on PC. Sugar spots were detected with silver nitrate reagent ${ }^{3)}$ PC: $R f 0.36$ in solvent B (Dglucose 0.36 ) and 0.46 in solvent C (D-glucose 0.46).

7) Enzymatic hydrolysis products of Compound $V$. Compound V $(2 \mathrm{mg})$ was digested with $\beta$-glucosidase $(2 \mathrm{mg})$ in a $0.2 \mathrm{M}$ acetate buffer solution $(1 \mathrm{ml}, \mathrm{pH} 5.5)$ at $37^{\circ} \mathrm{C}$ for $24 \mathrm{hr}$. To the mixture was added a small amount 
of water, and the aqueous solution was extracted with chloroform. After removal of the chloroform, the residue was used for comparison with an authentic sample on TLC. TLC: $R f 0.55$ in solvent A. The aqueous layer was used for the identification of sugar on PC. PC: Rf 0.35 in solvent $B$ and 0.46 in solvent $C$.

\section{Synthesis of 7-hydroxy-6-methoxychromone (5)}

1) 4-Benzyloxy-2-hydroxyacetophenone (1). After resacetophenone $(10 \mathrm{~g})$ had been dissolved in dry acetone $(50 \mathrm{ml})$, the solution was refluxed with benzyl chloride $(15 \mathrm{ml})$ and anhydrous potassium carbonate $(10 \mathrm{~g})$ for $3 \mathrm{hr}$. The mixture was cooled and treated with aqueous $10 \%$ hydrochloric acid. The solution was extracted with chloroform. Upon evaporation of the chloroform, the residue was chromatographed on a silica gel column. The eluate of benzene was concentrated to give $1(5.2 \mathrm{~g}, 32.8 \%)$ as colorless plates. mp: $99 \sim 100^{\circ} \mathrm{C}$ (lit. ${ }^{10)} 103 \sim 104^{\circ} \mathrm{C}$ ). Found: $\mathrm{C}, 74.40 ; \mathrm{H}, 5.85$. Calcd.for $\mathrm{C}_{15} \mathrm{H}_{14} \mathrm{O}_{3}$ : C, 74.36; $\mathrm{H}, 5.82 \%$. UV $\lambda_{\max }^{\mathrm{EtOH}} \mathrm{nm}(\log \varepsilon): 227$ (4.07), 274 (4.24), 314

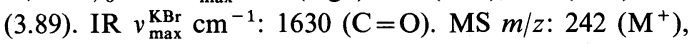
227, 91 (base peak). NMR $\delta_{\text {TMS }}^{\text {acetone- } d_{6}} \mathrm{ppm}: 12.45(1 \mathrm{H}, \mathrm{s}$, $\mathrm{OH}), 7.59(1 \mathrm{H}, \mathrm{d}, J=8 \mathrm{~Hz}, \mathrm{H}-6), 7.09 \sim 7.29(5 \mathrm{H}, \mathrm{m}$, phenyl proton), $6.25 \sim 6.43(2 \mathrm{H}, \mathrm{m}, \mathrm{H}-3,5), 4.99(2 \mathrm{H}, \mathrm{s}$, $\left.\mathrm{CH}_{2}\right), 2.35(3 \mathrm{H}, \mathrm{s}, \mathrm{AcO})$.

2) 4-Benzyloxy-2,5-dihydroxyacetophenone (2). After 1 $(4 \mathrm{~g})$ had been dissolved in pyridine $(80 \mathrm{ml})$ and aqueous $6 \%$ sodium hydroxide $(80 \mathrm{ml})$, to this solution thus obtained was added dropwise aqueous $8.4 \%$ potassium persulfate $(100 \mathrm{ml})$ during $3 \mathrm{hr}$ at $10^{\circ} \mathrm{C}$. After standing for $24 \mathrm{hr}$, the reaction mixture was acidified with $6 \mathrm{~N}$ hydrochloric acid and the precipitate was filtered off. The filtrate was treated with sodium sulfite $(8 \mathrm{~g})$ and conc. hydrochloric acid $(100 \mathrm{ml})$ and kept on a boiling water bath for $30 \mathrm{~min}$. On cooling, the golden yellow needles crystallized in the reaction mixture were collected and washed with water, and then chromatographed on a silica gel column. The eluate of chloroform was concentrated to give $2(1.1 \mathrm{~g}, 25.8 \%)$ as pale yellow needles. $\mathrm{mp}$ : $162 \sim 163^{\circ} \mathrm{C}$ (lit. $^{10)} 159 \sim 160^{\circ} \mathrm{C}$ ). Found: C, 69.71; H, 5.48. Calcd. for $\mathrm{C}_{15} \mathrm{H}_{14} \mathrm{O}_{4}: \mathrm{C}, 69.75 ; \mathrm{H}, 5.46 \%$. UV $\lambda_{\max }^{\mathrm{EtOH}} \mathrm{nm}$ ( $\log \varepsilon$ ): 240 (4.15), 277 (4.04), 350 (3.84). IR $v_{\max }^{\mathrm{KBr}} \mathrm{cm}^{-1}$ : $1645(\mathrm{C}=\mathrm{O})$. MS m/z: $258\left(\mathrm{M}^{+}\right), 167,91$ (base peak). NMR $\delta_{\text {TMS }}^{\text {acetone- } d_{6}}$ ppm: $12.39(1 \mathrm{H}, \mathrm{s}, \mathrm{OH}-2), 7.60(1 \mathrm{H}, \mathrm{s}$, $\mathrm{OH}-5), 7.32 \sim 7.56(5 \mathrm{H}, \mathrm{m}$, phenyl proton $), 7.25(1 \mathrm{H}, \mathrm{s}, \mathrm{H}-$ 6), $6.56(1 \mathrm{H}, \mathrm{s}, \mathrm{H}-3), 5.24\left(2 \mathrm{H}, \mathrm{s}, \mathrm{CH}_{2}\right), 2.52(3 \mathrm{H}, \mathrm{s}, \mathrm{AcO})$.

3) 4-Benzyloxy-2-hydroxy-5-methoxyacetophenone (3). The compound $2(1.3 \mathrm{~g})$ was refluxed with dimethyl sulfate $(0.5 \mathrm{ml})$, dry acetone $(60 \mathrm{ml})$ and anhydrous potassium carbonate $(3 \mathrm{~g})$ for $8 \mathrm{hr}$. After cooling, the reaction mixture was treated with aqueous $10 \%$ hydrochloric acid and extracted with chloroform. Upon evaporation of the chloroform, the residue was chromatographed on a silica gel column. The eluate of the chloroform was concentrated to give $3(875 \mathrm{mg}, 63.8 \%)$ as pale yellow needles. $\mathrm{mp}$ : $127 \sim 128^{\circ} \mathrm{C}$ (lit. $^{10)} 128 \sim 129^{\circ} \mathrm{C}$ ). Found: C, 70.76; H, 6.08. Calcd. for $\mathrm{C}_{16} \mathrm{H}_{16} \mathrm{O}_{4}: \mathrm{C}, 70.57 ; \mathrm{H}, 5.92 \%$ UV $\lambda \underset{\max }{\mathrm{EtOH}} \mathrm{nm}$ (log $\varepsilon): 236$ (4.13), 276 (4.07), 340 (3.81). IR $v_{\max }^{\mathrm{KBr}} \mathrm{cm}^{-1}$ : $1630(\mathrm{C}=\mathrm{O})$. MS m/z: $272\left(\mathrm{M}^{+}\right), 91$ (base peak). NMR $\delta_{\text {TMS }}^{\text {acetone- } d_{6}}$ ppm: $12.54(1 \mathrm{H}, \mathrm{s}, \mathrm{OH}), 7.32 \sim 7.56(6 \mathrm{H}, \mathrm{m}, \mathrm{H}-6$ and phenyl proton), $6.57(1 \mathrm{H}, \mathrm{s}, \mathrm{H}-3), 5.22\left(2 \mathrm{H}, \mathrm{s}, \mathrm{CH}_{2}\right)$, $3.82(3 \mathrm{H}, \mathrm{s}, \mathrm{MeO}), 2.57(3 \mathrm{H}, \mathrm{s}, \mathrm{AcO})$.

4) 7-Benzyloxy-2-hydroxy-6-methoxychromanone (4). To a solution of $3(300 \mathrm{mg})$ in ethyl formate $(4 \mathrm{ml})$ was added in steps pulverized sodium $(200 \mathrm{mg})$ while chilling with ice-cooled water. The reaction mixture was allowed to stand for $20 \mathrm{~min}$ and refluxed for $10 \mathrm{~min}$. After standing at room temperature for $24 \mathrm{hr}$, it yielded yellow solids, which were carefully, in limited amounts, added to icecooled water with stirring. The aqueous mixture thus obtained was washed three times with an adequate amount of ether, and then acidified with acetic acid to deposit the precipitates. The precipitates collected by filtration were chromatographed on a silica gel column. The eluate of the chloroform-ethanol mixture $(19: 1)$ was concentrated to give $4(198 \mathrm{mg}, 59.8 \%)$ as yellow needles. $\mathrm{mp}: 174 \sim 175^{\circ} \mathrm{C}$. Found: $\mathrm{C}, 68.12 ; \mathrm{H}, 5.36$. Calcd. for $\mathrm{C}_{17} \mathrm{H}_{16} \mathrm{O}_{5}$ : C, 67.99; $\mathrm{H}, 5.37 \%$. UV $\lambda_{\max }^{\mathrm{EtOH}} \mathrm{nm}(\log \varepsilon): 236(4.20), 273$ (4.08), 334 (3.87). IR $v_{\max }^{\mathrm{KBr}} \mathrm{cm}^{-1}: 1643(\mathrm{C}=\mathrm{O}) . \mathrm{MS} m / z: 300\left(\mathrm{M}^{+}\right)$, 282, 93 (base peak). NMR $\delta_{\text {TMS }}^{\text {acetone- } d_{6}}$ ppm: $7.3 \sim 7.6(5 \mathrm{H}$, $\mathrm{m}$, phenyl proton), $7.22(1 \mathrm{H}, \mathrm{s}, \mathrm{H}-5), 6.60(1 \mathrm{H}, \mathrm{s}, \mathrm{H}-8)$, $6.40 \sim 6.48(1 \mathrm{H}, \mathrm{d}, J=6 \mathrm{~Hz}, \mathrm{OH}), 5.72 \sim 5.90(1 \mathrm{H}, \mathrm{m}, \mathrm{H}-$ 2), $5.20\left(2 \mathrm{H}, \mathrm{s}, \mathrm{CH}_{2}\right), 3.80(3 \mathrm{H}, \mathrm{s}, \mathrm{MeO}), 2.68 \sim 2.90(2 \mathrm{H}$, $\mathrm{m}, \mathrm{H}-3)$.

5) 7-Hydroxy-6-methoxychromone (5). A solution of 4 $(127 \mathrm{mg})$ in a conc. hydrochloric acid-acetic acid mixture $(1: 1, \mathrm{v} / \mathrm{v}, 2 \mathrm{ml})$ was heated at $65^{\circ} \mathrm{C}$ for $2 \mathrm{hr}$. The reaction mixture was evaporated to dryness and the residue was chromatographed on a silica gel column. The eluate with chloroform was concentrated to give $\mathbf{5}(72 \mathrm{mg}, 88.5 \%)$ as colorless needles. mp: $233^{\circ} \mathrm{C}$. Found: C, $62.48 ; \mathrm{H}, 4.38$. Calcd. for $\mathrm{C}_{10} \mathrm{H}_{8} \mathrm{O}_{4}: \mathrm{C}, 62.50 ; \mathrm{H}, 4.20$. UV $\lambda{ }_{\max }^{\mathrm{EtOH}} \mathrm{nm}(\log \varepsilon)$ : 226 (4.12), $233 \mathrm{sh}$ (4.10), 279 (3.67), 316 (3.90). IR $v_{\max }^{\mathrm{KBr}}$ $\mathrm{cm}^{-1}: 1640(\mathrm{C}=\mathrm{O}), \mathrm{MS} m / z: 192\left(\mathrm{M}^{+}\right.$, base peak), 191, $177,163,149$. NMR $\delta_{\mathrm{TMS}}^{\mathrm{DMSO}-d_{6}} \mathrm{ppm}: 8.12(1 \mathrm{H}, \mathrm{d}, J=6 \mathrm{~Hz}$, H-2), 7.34 (1H, s, H-5), 6.92 (1H, s, H-8), 6.21 (1H, d, $J=$ $6 \mathrm{~Hz}, \mathrm{H}-3), 3.87(3 \mathrm{H}, \mathrm{s}, \mathrm{MeO})$.

This synthesized chromone was identical with the natural product Compound IV and aglycone of Compound $\mathrm{V}$ in its spectral data.

\section{REFERENCES}

1) Y. Arakawa, Y. Asada, H. Ishida, H. Chiji and M. Izawa, J. Fac. Agr. Hokkaido Univ., 61, 1 (1982).

2) R. Dreywood, Ind. Eng. Chem. Anal. Ed., 18, 499 (1949).

3) W. E. Trevelyan, D. P. Procter and J. S. Harrison, Nature, 166, 444 (1950).

4) R. Pendse, A. V. Rama Rao and K. Venkataraman, Phytochemistry, 12, 2033 (1973).

5) G. Romussi and G. Ciarallio, Phytochemistry, 13, 2890 (1974). 
6) S. Fukushima, T. Noro, Y. Saiki, A. Ueno and Y. Akahori, Yakugaku Zasshi, 88, 1135 (1968).

7) D. Bourwieg, B. Janistyn, M. Stocker und R. Pohl, Arch. Pharm., 307, 131 (1974).

8) H. Chiji, T. Aiba and M.Izawa, Agric. Biol. Chem.,
42, 159 (1978)

9) G. H. Jones, J. B. Mackenzie, A. Robertson and W. B. Whalley, J. Chem. Soc., 562 (1949).

10) N. Adityachaudhury, C. L. Kirtaniya and B. Mukherjee, Tetrahedron, 27, 2111 (1971). 